\title{
Correction to: Izabela Steflja and Jessica Trisko Darden: Women as War Criminals: Gender, Agency and Justice
}

\section{Stanford, Stanford University Press, 2020, ISBN: 9781503627574}

\section{Haoliang Zhang ${ }^{1}$}

Published online: 25 October 2021

(c) Springer Nature B.V. 2021

\section{Correction to: Feminist Legal Studies https://doi.org/10.1007/s10691-021-09467-1}

In the original publication of this book review, the last name of one of the book's coauthors was mistakenly identified as "Darden" instead of "Trisko Darden" throughout the article.

The original article has been corrected.

Publisher's Note Springer Nature remains neutral with regard to jurisdictional claims in published maps and institutional affiliations.

The original article can be found online at https://doi.org/10.1007/s10691-021-09467-1.

\section{Haoliang Zhang}

nickspector04@gmail.com

1 Law School, Nanjing Normal University, Nanjing, China 